\title{
Diversity of Fungi in the Public Hand-pump Borehole Water in Onueke, Ezza Local Government Area, Ebonyi State, Nigeria
}

\author{
Onuorah Samuel*, Nwoke John, Odibo Frederick \\ Department of Applied Microbiology and Brewing, Nnamdi Azikiwe University, Nigeria
}

Copyright $\odot 2019$ by authors, all rights reserved. Authors agree that this article remains permanently open access under the terms of the Creative Commons Attribution License 4.0 International License

\begin{abstract}
The diversity of fungi in fifteen public hand-pump borehole water in Onueke, Ezza Local Government Area of Ebonyi State, Nigeria was studied during the dry and wet seasons using standard analytical procedures. The total moulds and yeasts counts were $2-8 \mathrm{cfu} / \mathrm{ml}$ and $1-5 \mathrm{cfu} / \mathrm{ml}$ respectively during the dry season and $3-12 \mathrm{cfu} / \mathrm{ml}$ and $1-4 \mathrm{cfu} / \mathrm{ml}$ respectively during the wet season. More moulds were isolated from the samples during the wet than the dry season while more yeasts were isolated during the dry than the wet season. The fungi were characterized and identified on the basis of their colonial, microscopic, biochemical and molecular characteristics as Candida albicans, Microsporum canis, Aspergillus fumigatus, Geotrichum candidum, Basidiobolus ranarum, Microsporum audouinii, Fonsecaea pedrosoi and Trichosporon cutaneum. More of the boreholes contained Candida albicans than the other isolates during both seasons. Candida albicans occurred most frequently in the water samples during both seasons while Fonsecaea pedrosoi had the lowest frequency of occurrence in the water samples during both seasons. All the isolates were resistant to Griseofulvin while they exhibited varying degree of resistance and sensitivity to the other antifungal agents used. This study indicated that the borehole water samples examined did not comply with the standard established by regulatory bodies for potable water and therefore must be adequately treated before drinking and use for domestic purposes as these fungi have been reported to cause diseases of humans and animals. Boiling, chlorination, sand filtration and exposure to ultraviolet radiation are recommended.
\end{abstract}

Keywords Diversity, Fungi, Hand-pump, Borehole, Water, Onueke

\section{Introduction}

Water is essential in the life of all living organisms, from the smallest plants and microorganisms, to the most complex living system known as human body [1,2]. It is key to health and more basic than all other essential things to life [3]. Batmanghelid [4] reported that since drinking water provides for cell function and its volume requirements, the decrease in daily water intake affects the efficiency of cells and other body activities.

Groundwater which is the water beneath the surface where all the voids in the rocks and soils are filled is a source of water for wells, boreholes and springs. A borehole is a hydraulic structure which when properly designed and constructed permits the economic withdrawal of water from an aquifer. Borehole water is obtained from boreholes drilled into the aquifer or groundwater zone, which is usually a fully saturated subterranean zone, some distance below the water table [5] and supports drinking water, livestock needs, irrigation, industrial and many commercial activities.

Borehole water has unique features, which render it suitable for public water supply [6]. It is particularly important as it accounts for about $88 \%$ of safe drinking water in rural areas, where populations are widely dispersed and the infrastructure needed for treatment and transportation of used surface water does not exist [7].The quality of borehole water is the resultant of all processes and reactions that act on the water from the moment it condensed in the atmosphere to the time it is discharged by a well or spring and varies from place to place and with the depth of the water table [8].

Serious ill health can be caused by water contaminated from faeces being passed or washed into rivers, streams, pools, wells or boreholes [9]. It has been reported that borehole water contamination can occur through many domestic wastewater and livestock manure especially if there is a puncture in a layer of soil [10]. These wastes and sewage deposited near the boreholes may travel with percolating rain water directly into the borehole or may travel along the well-wall or surrounding material of the drill-holes [10].

Microorganisms play a major role in determining water 
quality. The most dangerous forms of water pollution are caused when faecal contaminants such as Escherichia coli enter the water supply. Pathogens such as Salmonella spp, Shigella spp, Vibrio cholerae and Escherichia coli that are shed into water bodies through faecal contamination perpetuate many diseases $[11,12]$. Other agents of water borne diseases are Entamoeba histolytica, Balantidium coli, Giardia lamblia, Cryptococcus parvum [13] viruses and helminths [14].

The recent upsurge in human population in Onueke, Ezza South Local Government Area of Ebonyi State due to its nearness to Abakaliki, the State capital and the fact that public water supply is almost non-existent have made borehole water the major source of water supply in the area. Though indicator organisms are used as indices of water pollution, pathogenic fungi have also been isolated in water, therefore in this work, the diversity of fungi in fifteen public hand-pump borehole water in Onueke, Ebonyi State was studied with a view to determining the safety of such water supply for use by humans.

\section{Methods}

\subsection{Boreholes Location}

Fifteen public hand-pump boreholes were sampled during the dry (December, 2017-February, 2018) and the wet (May -July 2018) seasons. The boreholes were situated in the following locations within Onueke, the study area:

$\begin{array}{ll}\text { a. } & \text { Community Secondary School Amuzu } \\ \text { b. } & \text { Ntezi Amuzu } \\ \text { c. } & \text { UBA Road Onueke } \\ \text { d. } & \text { Orinte Playground Amuzu } \\ \text { e. Ndufu Amana Village Square } \\ \text { f. } & \text { Ochudo Estate Onueke } \\ \text { g. } & \text { Motor Park Onueke } \\ \text { h. } & \text { Umuanyingor Ndufu Ezzama } \\ \text { i. } & \text { Pie-Junction Ndufu Ezzama } \\ \text { j. } & \text { Sacred Heart Parish I Onueke } \\ \text { k. } & \text { Sacred Heart Parish II Onueke } \\ \text { 1. } & \text { Ezza High School Amuzu } \\ \text { m. } & \text { Oferekpe Playground I Ezzama } \\ \text { n. } & \text { Central School Onueke } \\ \text { o. } & \text { Oferekpe Playground II Ezzama }\end{array}$

\subsection{Samples Collection and Processing}

Samples were collected in sterile one litre screw-capped containers that had been rinsed with $70 \%$ ethanol, distilled water and the water samples. The nozzles of the boreholes taps were sterilized with a spirit lamp and the water was allowed to run for five minutes before each of the containers was aseptically uncapped, filled with the water samples and recapped immediately. The samples were thereafter transported to the laboratory in ice-packed containers and analyzed within twenty four hours of collection. The samples were thoroughly mixed by inverting the containers for twenty five times before the analysis was carried out.

\subsection{Total Moulds Counts}

The spread plate technique as described by Cheesbrough [9] was used. Sabouraud Dextrose Agar (SDA) was prepared and sterilized in the autoclave at $121^{\circ} \mathrm{C}$ for fifteen minutes. It was allowed to cool to $45^{\circ} \mathrm{C}$ before introduction into sterile culture plates containing $0.05 \mathrm{mg} / \mathrm{ml}$ of chloramphenicol which was added to inhibit bacterial growth. The medium was allowed to solidify after which one milliliter of the water sample was dispensed with a sterile pipette into the centre of the solidified medium and spread evenly with a sterile glass rod. Incubation was carried out in an inverted position at $28^{\circ} \mathrm{C}$ for seven days after which the colonies that developed were counted and recorded. Each colony was purified by repeated subculturing on sterile SDA plate and later stored on sterile SDA slant for characterization and identification.

\subsection{Total Yeasts Counts}

This was carried out using the spread plate technique as described by Cheesbrough [9]. One milliliter of the water sample was dispensed into the centre of a sterile culture plate containing sterile solidified Malt Yeast Extract Agar (MYEA) and $0.05 \mathrm{mg} / \mathrm{ml}$ of chloramphenicol was added to inhibit bacterial growth and evenly spread with a sterile glass rod. The plate was thereafter covered and incubated in an inverted position at $28^{\circ} \mathrm{C}$ for seven days after which the colonies that developed were counted and recorded. Each of the colonies was subcultured on sterile MYEA plate and later stored on sterile MYEA slant for further studies.

\subsection{Characterization and Identification of the Fungal Isolates}

The fungal isolates were characterized on the basis of their colonial, cellular, biochemical and molecular characteristics. Colony morphology (color, elevation, margin), cellular morphology (shape and cellular arrangement), gram staining, germ tube test, sugar fermentation test, urease test, slide culture test and motility test were carried out as done by Cheesbrough [9]. Molecular characterization was carried out using 17 srRNA. The isolates were identified according to the description of David et al. [15].

\subsection{Antifungal Susceptibility Tests of the Fungal Isolates}

\subsubsection{Yeasts}

The antifungal susceptibility test of the yeasts was 
carried out as done by Cheesbrough [9] using Mueller Hinton Agar. The medium was prepared, sterilized in the autoclave at $121^{\circ} \mathrm{C}$ for fifteen minutes and introduced into sterile culture plates to a depth of $4 \mathrm{~mm}$. A pure isolate was emulsified in a small volume of peptone water. The turbidity of the suspension was matched against Mcfarland standard. $0.1 \mathrm{ml}$ of the suspension of the test organism was introduced into the agar plate with a sterile pipette and spread over the surface of the medium with a sterile glass rod. A sterile borer was used to bore wells on the agar and $0.2 \mathrm{ml}$ of the test antifungal agent was injected into each of the wells. The culture plates were incubated at $37^{\circ} \mathrm{C}$ for three days and zones of inhibition were measured with a compass which was thereafter matched against a meter rule. The antifungal agents tested were Clotrimazole, Nystatin, Fluconazole and Griseofulvin.

\subsubsection{Moulds}

The test was also carried out as done by Cheesbrough [9] using Mueller Hinton Agar. Sporulating pure cultures of the moulds were vortexed in sterile distilled water to release the spores. $0.1 \mathrm{ml}$ of the spore suspension was aseptically collected using a sterile pipette and introduced into the medium contained in a Petri dish. The sample was spread on the surface of the medium using a sterile glass rod. A sterile borer was used to bore wells in the agar and $0.2 \mathrm{ml}$ of the test drug was injected into each of the wells. The Petri dishes were incubated at $37^{\circ} \mathrm{C}$ for three days and the zones of inhibition were measured using a compass which was thereafter matched against a meter rule to obtain the exact values.

\subsection{Statistical Analysis of Data}

Statistical analysis of the data obtained during both seasons was carried out using 1BM SPSS package, version 20.

\section{Results}

The total fungal counts of the public hand-pump borehole water samples during the dry season are shown in Table 1 . The total moulds counts ranged from 2 to $8 \mathrm{cfu} / \mathrm{ml}$ while the total yeasts counts ranged between 1 and $5 \mathrm{cfu} / \mathrm{ml}$.

The total fungal counts of the public hand-pump borehole water samples during the wet season are presented in Table 2 . The total moulds counts were $3-12 \mathrm{cfu} / \mathrm{ml}$ while the total yeasts counts ranged from 1 to 4 $\mathrm{cfu} / \mathrm{ml}$.

Table 1. Total fungal counts of the public hand-pump borehole water samples during the dry season

\begin{tabular}{llc}
\hline \multicolumn{1}{c}{ Sample location } & Total moulds counts (cfu/ml) & Total yeasts counts (cfu/ml) \\
\hline Community Secondary School Amuzu & 3 & 2 \\
\hline Ntezi Amuzu & 2 & 1 \\
\hline UBA Road Onueke & 4 & 3 \\
\hline Orinte Playground Amuzu & 3 & 2 \\
\hline Ndufu Amana & 3 & 2 \\
\hline Ochudo Estate Onueke & 5 & 3 \\
\hline Motor Park Onueke & 6 & 1 \\
\hline Umuanyingor Ndufu Ezzama & 4 & 3 \\
\hline Pie Junction Ndufu Ezzama & 3 & 2 \\
\hline Sacred Heart Parish I Onueke & 4 & 3 \\
\hline Sacred Heart Parish II Onueke & 5 & 4 \\
\hline Ezza High School Amuzu & 8 & 5 \\
\hline Oferekpe Playground I Ezzama & 4 & 3 \\
\hline Central School Onueke & 3 & 2 \\
\hline Oferekpe Playground II Ezzama & 3 & 1 \\
\hline WHO Standard & 0 & 0 \\
\hline
\end{tabular}

$\mathrm{WHO}=$ world health organization

$\mathrm{cfu} / \mathrm{ml}=$ colony forming unit per milliliter of water sample. 
Table 2. Total fungal counts of the public hand-pump borehole water samples during the wet season

\begin{tabular}{llc}
\hline \multicolumn{1}{c}{ Sample location } & Total moulds counts (cfu/ml) & Total yeasts counts (cfu/ml) \\
\hline Community Secondary School Amuzu & 5 & 1 \\
\hline Ntezi Amuzu & 3 & 1 \\
\hline UBA Road Onueke & 6 & 2 \\
\hline Orinte Playground Amuzu & 4 & 1 \\
\hline Ndufu Amana & 3 & 2 \\
\hline Ochudo Estate Onueke & 6 & 2 \\
\hline Motor Park Onueke & 11 & 1 \\
\hline Umuanyingor Ndufu Ezzama & 6 & 2 \\
\hline Pie Junction Ndufu Ezzama & 6 & 2 \\
\hline Sacred Heart Parish I Onueke & 5 & 3 \\
\hline Sacred Heart Parish II Onueke & 12 & 3 \\
\hline Ezza High School Amuzu & 9 & 4 \\
\hline Oferekpe Playground I Ezzama & 5 & 2 \\
\hline Central School Onueke & 4 & 1 \\
\hline Oferekpe Playground II Ezzama & 5 & 1 \\
\hline WHO Standard & 0 & 0 \\
\hline
\end{tabular}

$\mathrm{WHO}=$ world health organization

$\mathrm{cfu} / \mathrm{ml}=$ colony forming unit per milliliter of water sample

Table 3. Colonial and microscopic characteristics of the moulds isolated from the public hand-pump borehole water samples during the dry and wet seasons

\begin{tabular}{llll}
\hline Isolates & Colonial Characteristics & Microscopic Characteristics & Identity \\
\hline 1 & $\begin{array}{l}\text { Colonies were heaped-up, white in colour with a dense } \\
\text { surface and bright yellow reverse. }\end{array}$ & $\begin{array}{l}\text { Macroconidia were spindle-shaped with 6-15 cells } \\
\text { and were thick-walled. }\end{array}$ & $\begin{array}{l}\text { Microsporium } \\
\text { canis }\end{array}$ \\
\hline 2 & $\begin{array}{l}\text { Colonies were rapidly growing and velvety in texture. } \\
\text { The colour was dark green on the surface and the } \\
\text { reverse side was yellow. }\end{array}$ & $\begin{array}{l}\text { Conidiophores were short, smooth and densely } \\
\text { crowded. The conidia were spherical and formed a } \\
\text { columnar mass which was green in colour. }\end{array}$ & $\begin{array}{l}\text { Aspergillus } \\
\text { fumigatus }\end{array}$ \\
\hline 3 & $\begin{array}{l}\text { Colonies were yeast-like with heaped-up surface } \\
\text { contour and the reverse side was white in colour. }\end{array}$ & $\begin{array}{l}\text { Septate, branching hyphae and arthrospores were } \\
\text { seen. The arthrospores were not separated from each } \\
\text { other by empty space. }\end{array}$ & $\begin{array}{l}\text { Geotrichum } \\
\text { candidum }\end{array}$ \\
\hline 4 & $\begin{array}{l}\text { Colonies were initially flat and waxy but later became } \\
\text { heaped-up and folded. The surface was covered with } \\
\text { whitish aerial mycelium and the colour was grey. }\end{array}$ & $\begin{array}{l}\text { Hyphae were septate, zygospores were spherical, } \\
\text { thick, smooth-walled and bore a single peripheral } \\
\text { beak. }\end{array}$ & $\begin{array}{l}\text { Basidiobolus } \\
\text { ranarum }\end{array}$ \\
\hline 5 & $\begin{array}{l}\text { Colonies were waxy, folded, with filamentous fringes } \\
\text { and orange-yellow in colour. The reverse side was } \\
\text { rusty-red in colour. }\end{array}$ & $\begin{array}{l}\text { Hyphae were long, straight and irregularly } \\
\text { branched, with prominent cross walls. } \\
\text { Microaleurospores were absent. }\end{array}$ & $\begin{array}{l}\text { Microsporium } \\
\text { audouinii }\end{array}$ \\
\hline 6 & $\begin{array}{l}\text { Colonies were slow growing, heaped-up, brittle with } \\
\text { scanty aerial mycelium. The colour was brownish } \\
\text { along its hyphae. }\end{array}$ & $\begin{array}{l}\text { Conidia were spherical and formed a compact head } \\
\text { that was not easily dissociated. }\end{array}$ & $\begin{array}{l}\text { Fonsecaea } \\
\text { pedrosoi }\end{array}$ \\
\hline
\end{tabular}

Table 3 showed the colonial and microscopic characteristics of the moulds from the public hand-pump borehole water samples during the dry and wet seasons. They were identified as Microsporium canis,Aspergillus fumigatus, Geotrichum candidum, Basidiobolus ranarum, Microsporium audouinii, Fonsecaea pedrosoi and

\section{Trichosporon cutaneum.}

The characteristics of the yeasts isolated from the public hand-pump borehole water samples during the dry and wet seasons are shown in Table 4. They were identified as Candida albicans. 
Table 4. Characteristics of the yeasts isolated from the public hand-pump borehole water samples during the dry and wet seasons

\begin{tabular}{ll}
\hline Parameters & Result \\
\hline Colour & Cream \\
\hline Shape & Oval \\
\hline Germ tube formation & - \\
\hline Motility & - \\
\hline Urease production & + \\
\hline Glucose fermentation & - \\
\hline Lactose fermentation & - \\
\hline Mannitol fermentation & - \\
\hline Sucrose fermentation & Candida albicans \\
\hline Identity &
\end{tabular}

Table 5. Distribution of the fungal isolates in the public hand-pump borehole water samples during the dry season

\begin{tabular}{|c|c|c|c|c|c|c|c|c|}
\hline $\begin{array}{l}\text { Sample } \\
\text { location }\end{array}$ & $\begin{array}{l}\text { Candida } \\
\text { albicans }\end{array}$ & $\begin{array}{l}\text { Microsporium } \\
\text { canis }\end{array}$ & $\begin{array}{l}\text { Aspergillus } \\
\text { fumigatus }\end{array}$ & $\begin{array}{l}\text { Geotrichum } \\
\text { candidum }\end{array}$ & $\begin{array}{c}\text { Microsporium } \\
\text { audouinii }\end{array}$ & $\begin{array}{c}\text { Basidiobolus } \\
\text { ranarum }\end{array}$ & $\begin{array}{c}\text { Fonsecaea } \\
\text { pedrosoi }\end{array}$ & $\begin{array}{c}\text { Trichosporon } \\
\text { cutaneum }\end{array}$ \\
\hline $\begin{array}{l}\text { Community } \\
\text { Secondary } \\
\text { School } \\
\text { Amuzu }\end{array}$ & + & 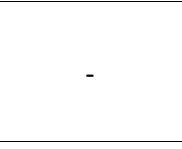 & - & + & - & - & - & - \\
\hline Ntezi Amuzu & - & - & - & - & - & - & - & + \\
\hline $\begin{array}{l}\text { UBA Road } \\
\text { Onueke }\end{array}$ & + & - & + & - & - & - & - & - \\
\hline $\begin{array}{l}\text { Orinte } \\
\text { Playground } \\
\text { Amuzu }\end{array}$ & - & - & - & - & + & - & - & - \\
\hline $\begin{array}{l}\text { Ndufu } \\
\text { Amana }\end{array}$ & + & - & - & - & - & - & - & + \\
\hline $\begin{array}{l}\text { Ochudo } \\
\text { Estate } \\
\text { Onueke }\end{array}$ & - & + & - & - & - & - & - & - \\
\hline $\begin{array}{l}\text { Motor Park } \\
\text { Onueke }\end{array}$ & + & - & - & - & - & - & - & - \\
\hline $\begin{array}{l}\text { Umuanyingor } \\
\text { Ndufu } \\
\text { Ezzama }\end{array}$ & - & - & - & - & - & - & + & - \\
\hline $\begin{array}{l}\text { Pie Junction } \\
\text { Ndufu } \\
\text { Ezzama }\end{array}$ & - & - & - & - & - & + & - & - \\
\hline $\begin{array}{l}\text { Sacred Heart } \\
\text { Parish I } \\
\text { Onueke }\end{array}$ & - & + & - & - & - & - & - & - \\
\hline $\begin{array}{l}\text { Sacred Heart } \\
\text { Parish II } \\
\text { Onueke } \\
\end{array}$ & + & - & - & + & - & - & - & - \\
\hline $\begin{array}{l}\text { Ezza High } \\
\text { School } \\
\text { Amuzu }\end{array}$ & + & - & - & - & - & - & - & - \\
\hline $\begin{array}{l}\text { Oferekpe } \\
\text { Playground I } \\
\text { Ezzama }\end{array}$ & - & - & - & - & + & - & - & - \\
\hline $\begin{array}{l}\text { Central } \\
\text { School } \\
\text { Onueke }\end{array}$ & - & - & - & - & - & + & - & - \\
\hline $\begin{array}{l}\text { Oferekpe } \\
\text { Playground II } \\
\text { Ezzama }\end{array}$ & - & + & - & - & - & - & - & - \\
\hline
\end{tabular}

$+=$ detected

- = not detected 
The distribution of the fungal isolates in the public hand-pump borehole water samples during the dry season is shown in Table 5. Six (40.0\%), five (20.0\%), one (6.7\%), two $(13.3 \%)$, two (13.3\%), two (13.3\%), one $(6.7 \%)$ and two (13.3\%) of the boreholes studied had Candida albicans, Microsporium canis, Aspergillus fumigatus, Geotrichum candidum, Microsporium audouinii, Basidiobolus ranarum, Fonsecaea pedrosoi and Trichosporon cutaneum respectively.
Table 6 showed the occurrence of the fungal isolates in the public hand-pump borehole water samples during the wet season. Five (33.3\%), four (26.7\%), two (13.3\%), three $(20.0 \%)$, four $(26.7 \%)$, three $(20.0 \%)$, two $(13.3 \%)$ and three $(20.0 \%)$ of the boreholes studied had Candida albicans, Microsporium canis, Aspergillus fumigatus, Geotrichum candidum, Microsporium audouinii, Basidiobolus ranarum, Fonsecaea pedrosoi and Trichosporon cutaneum respectively.

Table 6. Distribution of the fungal isolates in the public hand-pump borehole water samples during the wet season

\begin{tabular}{|c|c|c|c|c|c|c|c|c|}
\hline $\begin{array}{c}\text { Sample } \\
\text { location }\end{array}$ & $\begin{array}{l}\text { Candida } \\
\text { albicans }\end{array}$ & $\begin{array}{l}\text { Microsporium } \\
\text { canis } \\
\end{array}$ & $\begin{array}{c}\text { Aspergillus } \\
\text { fumigatus }\end{array}$ & $\begin{array}{c}\text { Geotrichum } \\
\text { candidum }\end{array}$ & $\begin{array}{c}\text { Microsporium } \\
\text { audouinii }\end{array}$ & $\begin{array}{c}\text { Basidiobolus } \\
\text { ranarum }\end{array}$ & $\begin{array}{c}\text { Fonsecaea } \\
\text { pedrosoi }\end{array}$ & $\begin{array}{c}\text { Trichosporon } \\
\text { cutaneum }\end{array}$ \\
\hline $\begin{array}{l}\text { Community } \\
\text { Secondary } \\
\text { School } \\
\text { Amuzu }\end{array}$ & + & - & - & + & - & - & - & - \\
\hline Ntezi Amuzu & - & - & - & - & - & + & - & + \\
\hline $\begin{array}{l}\text { UBA Road } \\
\text { Onueke }\end{array}$ & - & + & + & - & - & - & - & - \\
\hline $\begin{array}{l}\text { Orinte } \\
\text { Playground } \\
\text { Amuzu }\end{array}$ & - & - & - & - & + & - & - & - \\
\hline $\begin{array}{l}\text { Ndufu } \\
\text { Amana }\end{array}$ & + & - & - & - & + & - & - & + \\
\hline $\begin{array}{l}\text { Ochudo } \\
\text { Estate } \\
\text { Onueke }\end{array}$ & - & + & - & + & - & - & - & - \\
\hline $\begin{array}{l}\text { Motor Park } \\
\text { Onueke }\end{array}$ & + & - & - & - & - & - & - & - \\
\hline $\begin{array}{l}\text { Umuanyingor } \\
\text { Ndufu } \\
\text { Ezzama }\end{array}$ & - & - & + & - & - & - & + & - \\
\hline $\begin{array}{l}\text { Pie Junction } \\
\text { Ndufu } \\
\text { Ezzama }\end{array}$ & - & - & - & - & - & + & - & - \\
\hline $\begin{array}{l}\text { Sacred Heart } \\
\text { Parish I } \\
\text { Onueke }\end{array}$ & - & + & - & - & - & - & - & - \\
\hline $\begin{array}{l}\text { Sacred Heart } \\
\text { Parish II } \\
\text { Onueke }\end{array}$ & + & - & - & + & + & - & - & + \\
\hline $\begin{array}{l}\text { Ezza High } \\
\text { School } \\
\text { Amuzu }\end{array}$ & + & - & - & - & - & - & - & - \\
\hline $\begin{array}{l}\text { Oferekpe } \\
\text { Playground I } \\
\text { Ezzama }\end{array}$ & - & - & - & - & + & - & - & - \\
\hline $\begin{array}{l}\text { Central } \\
\text { School } \\
\text { Onueke }\end{array}$ & - & - & - & - & - & + & - & - \\
\hline $\begin{array}{l}\text { Oferekpe } \\
\text { Playground II } \\
\text { Ezzama }\end{array}$ & - & + & - & - & - & - & - & - \\
\hline
\end{tabular}


The frequency of occurrence of the fungi in the public hand-pump borehole water samples during the dry season is presented in Table 7. Candida albicans (26.8\%), Microsporium canis (17.5\%), Aspergillus fumigatus (6.2\%), Geotrichum candidum (10.3\%), Microsporium audouinii (15.5\%), Basidiobolus ranarum (12.4\%), Fonsecaea pedrosoi (4.1\%) and Trichosporon cutaneum(7.2\%) were isolated from the borehole water samples studied.

The frequency of occurrence of the fungi in the public hand-pump borehole water samples during the wet season is shown in Table 8. Candida albicans (19.3\%), Microsporium canis (18.5\%), Aspergillus fumigatus (7.6\%), Geotrichum candidum (11.8\%), Microsporium audouinii (16.0\%), Basidiobolus ranarum (12.6\%), Fonsecaea pedrosoi (5.0\%) and Trichosporon cutaneum (9.2\%) was recovered from the borehole water samples examined.

The susceptibility test of the fungal isolates to antifungal agents is shown in Table 9. Four $(50.0 \%)$, five $(62.5 \%)$ and one $(12.5 \%)$ of the fungal isolates were sensitive to Clotrimaxole, Nystatin and Fluconazole respectively while all the isolates were resistant to Griseofulvin.

Table 7. Frequency of occurrence of the fungi in the public hand-pump borehole water samples during the dry season

\begin{tabular}{lcc}
\hline Fungal isolates & Number of colonies isolated & Frequency of occurrence (\%) \\
\hline Candida albicans & 26 & 26.8 \\
\hline Microsporium canis & 17 & 17.5 \\
\hline Aspergillus fumigatus & 6 & 6.2 \\
\hline Geotrichum candidum & 10 & 10.3 \\
\hline Microsporium audouinii & 15 & 15.5 \\
\hline Basidiobolus ranarum & 12 & 12.4 \\
\hline Fonsecaea pedrosoi & 4 & 4.1 \\
\hline Trichosporon cutaneum & 7 & 7.2 \\
\hline Total & 97 & 100.0 \\
\hline
\end{tabular}

Table 8. Frequency of occurrence of the fungi in the public hand-pump borehole water samples during the wet season

\begin{tabular}{lcc}
\hline Fungal isolates & Number of colonies isolated & Frequency of occurrence (\%) \\
\hline Candida albicans & 23 & 19.3 \\
\hline Microsporium canis & 22 & 18.5 \\
\hline Aspergillus fumigatus & 9 & 7.6 \\
\hline Geotrichum candidum & 14 & 11.8 \\
\hline Microsporium audouinii & 19 & 16.0 \\
\hline Basidiobolus ranarum & 15 & 12.6 \\
\hline Fonsecaea pedrosoi & 6 & 5.0 \\
\hline Trichosporon cutaneum & 11 & 9.2 \\
\hline Total & 119 & 100.0 \\
\hline
\end{tabular}

Table 9. Susceptibility test of the fungal isolates to antifungal agents

\begin{tabular}{lcccc}
\hline Fungal isolates & Clotrimazole & Nystatin & Fluconazole & Griseofulvin \\
\hline Candida albicans & $\mathrm{R}$ & $\mathrm{S}$ & $\mathrm{S}$ & $\mathrm{R}$ \\
\hline Microsporium canis & $\mathrm{S}$ & $\mathrm{S}$ & $\mathrm{R}$ & $\mathrm{R}$ \\
\hline Aspergillus fumigatus & $\mathrm{R}$ & $\mathrm{S}$ & $\mathrm{R}$ & $\mathrm{R}$ \\
\hline Geotrichum candidum & $\mathrm{S}$ & $\mathrm{R}$ & $\mathrm{R}$ & $\mathrm{R}$ \\
\hline Microsporium audouinii & $\mathrm{S}$ & $\mathrm{R}$ & $\mathrm{R}$ & $\mathrm{R}$ \\
\hline Basidiobolus ranarum & $\mathrm{R}$ & $\mathrm{S}$ & $\mathrm{R}$ & $\mathrm{R}$ \\
\hline Fonsecaea pedrosoi & $\mathrm{S}$ & $\mathrm{S}$ & $\mathrm{R}$ & $\mathrm{R}$ \\
\hline Trichosporon cutaneum & $\mathrm{R}$ & $\mathrm{R}$ & $\mathrm{R}$ & $\mathrm{R}$ \\
\hline
\end{tabular}

$\mathrm{S}=$ sensitive

$\mathrm{R}=$ resistant 


\section{Discussion}

The total moulds counts of the public hand-pump borehole water samples examined ranged from $2-8 \mathrm{cfu} / \mathrm{ml}$ during the dry season (Table 1 ) and $3-12 \mathrm{cfu} / \mathrm{ml}$ during the wet season (Table 2). The results showed that more moulds were isolated from the samples during the wet season than the dry season. This may be attributed to the fact that moulds thrive better in moist than dry environments. The total yeasts counts of the public hand-pump borehole water samples studied were $1-5 \mathrm{cfu} / \mathrm{ml}$ during the dry season (Table 1) and 1-4 cfu/ml during the wet season (Table 2), indicating that more yeasts were isolated from the water samples during the dry than the wet season. This showed that the dry season was more favourable to their growth than the wet season

More fungi were isolated from the samples during the wet season than the dry season (Tables 1 and 2). This may be because of the flood which may have deposited its contents including nutrients and fungi near the boreholes resulting in their seepage into such boreholes. This result agreed with the report of Onuorah et al. [16] on the mycology of hand-dug shallow water wells in Awka Metropolis, Anambra State, Nigeria.

The moulds isolated from the borehole water samples examined during both seasons were Microsporium canis, Aspergillus fumigatus, Geotrichum candidum, Microsporium audouinii, Basidiobolus ranarum, Fonsecaea pedrosoi and Trichosporon cutaneum(Table 3) while Candida albicans was the only yeast isolated (Table 4). This result conformed to the work of Onuorah et al. (16] that reported Candida albicans and Microsporium canis in the shallow water wells they studied in Awka Metropolis, Nigeria and Warris et al. [17], Hayette et al. [18] and Anaissie et al. [19] that reported Aspergillus species in the drinking water samples they assessed.

The fungi were recovered from more borehole water samples during the wet season than the dry season. More borehole water samples contained the yeast Candida albicans than the other fungal isolates during both seasons (Table 5 and 6). The yeast Candida albicans had the highest frequency of occurrence of $26.8 \%$ during the dry season and $19.3 \%$ during the wet season in the borehole water samples analyzed (Tables 7 and 8). Fonsecaea pedrosoi however had the lowest frequency of occurrence of $4.1 \%$ and $5.0 \%$ during the dry and wet seasons respectively.

Warris et al.[17] reported that $21 \%$ of the drinking water samples they assessed were contaminated with Aspergillus species. Aspergillus species were also reported by Anaissie et al. [19] to be in more than $70 \%$ of all the drinking water samples they examined. In addition, Kanzler et al. [20] isolated basidiomycetes $(56.4 \%)$ in the water well samples they assessed. However, Onuorah et al. [16] isolated Candida albicans $(42.0 \%$ and $44.8 \%$ ) in the shallow water well samples in Awka Metropolis during the dry and rainy seasons respectively.

The fungal isolates exhibited varying degree of susceptibility and resistance to the antifungal agents used in the study. All the isolates were resistant to the drug Griseofulvin. Similar resistance pattern has been reported by Olajuba and Ogunika [21].Candida albicans is a dimorphic fungus and one of the genera that cause candidiasis in humans [22] and is responsible for $50-90 \%$ of all cases of candidiasis of humans. It is a flora of the human gastrointestinal tract and is detectable in the gastrointestinal tract in $40 \%$ of healthy adults [23].

Microsporium canis is a pathogenic dermatophyte that infects the upper dead layers of the skin of domesticated cats and occasionally dogs, horses and humans [24,25]. It has been identified as a causal agent of ringworm infections in pets, tinea capitis and tinea corporis in humans particularly in children. Microsporium canis may also persist as dormant spores in the environment for prolonged periods.

Aspergillus fumigatus is a spore forming mould commonly found in the soil, rotting vegetable matter, food items, household dust and building materials. It causes infections in immuno suppressed individuals such as AIDS patients [26] and allergic broncho-pulmonary aspergillosis in immuno competent hosts [27].

Geotrichum candidum is a common fungus commonly isolated from the soil, water, air and digestive tracts of humans and animals [28]. Pulmonary, bronchial, oral, vaginal, cutaneous and alimentary infections caused by this organism have been reported. Microsporium audouinii is a dermatophyte that is often found in the soil that is rich in keratinous materials [29]. It causes the infections tinea capitis and tinea corporis [30]

Basidiobolus ranarum is a filamentous fungus that can live saprophytically in the intestines of vertebrates (frogs, lizards, toads, turtles, salamanders), reptiles (chameleons, wall geckoes, snakes) and fishes [31,32], bats, compost heap, decaying plant material, soil, horses and are known to cause subcutaneous zygomycosis in humans and animals. Fonsecaea pedrosoi is commonly found in the soil, plants and trees in the tropical and sub-tropical regions [33]. It is the causative agent of a chronically progressive crusted ulceration of the skin known as chromoblastomycosis [34].

Trichosporon cutaneum is a yeast-like fungus that inhabits the respiratory and digestive tracts and skin of humans and animals and the soil. It causes an unpleasant but harmless hair condition called white piedra and trichosporonosis and has been recently reported as an opportunistic pathogen in immuno-compromised hosts. The infection caused by this organism can be invasive or unusual in appearance [35].

The presence of these fungi in the water samples may be attributed to the sanitary condition of the soil around the boreholes. There was significant correlation between the total moulds counts at $\mathrm{P}<0.05$ level during both seasons indicating that they were affected by seasonal variation. 
However, the total yeast counts were insignificant during both seasons showing that they were not affected by seasonal variation.

\section{Conclusions}

This work showed that the borehole water samples analyzed were contaminated with fungi. These fungi had been reported to cause diseases in humans and animals. It is therefore imperative to review the state of these boreholes water by periodically assessing their mycological quality. Informing the inhabitants of the area of the state of their drinking water should be considered as an important aspect of social responsibility and scientific research. In addition, such inhabitants should be sensitized on the need for the maintenance of adequate sanitation within the vicinity of the boreholes. Boiling, chlorination, sand filtration, coagulation and aeration of the water from such boreholes are recommended.

\section{REFERENCES}

[1] Onifade, A. K. and Ilori, R.M. (2008).Microbiological analysis of sachet water vended in Ondo State, Nigeria. Environmental and Research Journal.2 (3): 107-110.

[2] Ajewole, G. (2005). Water. An Overview. Nigeria Institute of Food Science and Technology, Nigeria.2: 4-15.

[3] Edungbola, L. D. and Asaolu, S. O. (1984). Parasitologic survey of onchocerciasis (river blindness) in Babana District, Kwara State, Nigeria. American Journal of Tropical Medicine and Hygiene. 33 (6): 1147-1154.

[4] Batmanghelid, R. (2009). Water and its vital role in the health of a water starved society. US National Research Council, Food and Nutrition Bureau (2). Pp 26-73.

[5] National Water Resources Institute (1997). Training Guide for Basic Water Treatment Operations, Kaduna.Pp 1.

[6] Okpokwasili, G. C. and Akujobi, T. C. (1996). Bacteriological indicators of tropical water quality. Environmental Toxicology and Water Quality. 11(2):77-82.

[7] Uhuo, C. A., Uneke, B.I., Okereke, C. N., Nwele, D. E. and Ogbanshi, M.E. (2014). The bacteriological survey of borehole waters in Peri-Urban areas of Abakaliki, Ebonyi State, Nigeria. International Journal of Bacteriology Research.2 (2): 28-31.

[8] Gardon, D. M. (2001). Geographical structure and host specificity in bacteria and the implication for tracing the source of coliform contamination. Microbiology. 147(5):1079-1085.

[9] Cheesbrough, M. (2006).District Laboratory Practice in Tropical Countries part 2. Cambridge University Press.Pp.143-157.

[10] Obi, C. N. and Okocha, C. O. (2007). Microbiological and
Physicochemical analysis of selected borehole waters in World Bank Housing Estate, Umuahia, Abia State Nigeria. Journal of Engineering and Applied Science. 257(5):920-929.

[11] Muchuweti, M., Birkeit, J. W., Chinyanga, E., Zvanya; Scrimshaw, M.D. and Lestes, J.N. (2006).Heavy metals content and sewage sludge in Zimbabwe; implications for human health. Agriculture, Ecosystem and Environment. 112:41-48.

[12] Faparusi, F., Ayedun, H. and Bello-Akinosho, M. M. (2011).Microbial and Physicochemical properties of ground water of Ilaro South West. International Journal of Biological and Chemical Sciences. 5(2): 500-506.

[13] Kelly, P., Baboo, K., Ndubani, P. and Farthing, M. J. G. (1997).Cryptosporidiosis in adults in Lusaka, Zambia and its relationship to Oocyst Contamination of Drinking Water. The Journal of Infectious Diseases.176 (4):1120-1123.

[14] Raji, M. I. O. and Ibrahim, Y. K. E. (2011).Prevalence of water borne infections in Northwest Nigeria: A retrospective study .Journal of Public Health and Epidemiology.3 (8):382-385

[15] David, E., Stephen, D., Helen, A., Rosemary, H. and Robyn, B. (2007).Descriptions of Medical Fungi. School of Molecular and Biomedical Science. University of Adelaide. $2^{\text {nd }}$ edition. Pp58.

[16] Onuorah Samuel, Elesia Rosemary and Odibo Frederick (2016).Mycology of Hand-dug Shallow Water Wells in Awka Metropolis, Anambra State, Nigeria. Advances in Zoology and Botany.4 (2): 17-22.

[17] Warris, A., Gaustad, P., Meis, J.F; Voss, A; Verweij, P.E. and Brahamsen, T. G. (2001).Recovery of Filamentous fungi from water in a paediatric bone marrow transplantation unit. Journal of Hospital Infection. 47:143-148.

[18] Hayette, M. P., Christiaens, G., Mutsers, J., Barbier, C., Huynen, P., Melin, P. and De Mol, P. (2010). Filamentous fungi recovered from the water distribution system of a Belgian University Hospital. Medical Mycology Official Publication of the International Society for Human and Animal Mycology.48 (7): 969-974.

[19] Anaissie, E. J., Stratton, S. L., Dignani, M. C; Lee, C. K., Summerbell, R.C. and Rex, J.H. (2002). Pathogenic Aspergillus species recovered from a hospital water system: a 3-year prospective study. Clinical Infectious Diseases. 34:780-789.

[20] Kanzler, D; Buzin, W; Paulitsch, A; Hass, D; Platzer, S Marth, E. and Mascher, D. (2007).Occurrences and hygienic relevance of fungi in drinking water.Mycoses.51 (2):165-169.

[21] Olajubu, F. A. and Ogunika, F. (2014). Assessment of the Physicochemical and Microbiological properties of borehole water samples from Akungba-Akoko, Ondo State, Nigeria. International Journal of Pharmaceutical Science and Research.5 (7): 367-374.

[22] Erdogan, A. and Rao, S. S. (2015).Small intestinal fungal overgrowth. Current Gastroenterology Reports.17 (4):16.

[23] Mukherjee, P. K., Sendid, B; Hoarau, G; Colombel, J. F; 
Paulain D. and Ghannoum, M. A. (2015). Mycobiota in gastrointestinal diseases. Nature Reviews. Gastroenterology and Hepatology.12 (2):77-87.

[24] Shafiee, S; Khosravi, A. R. and Tamai, I. A. (2014). Comparative Study of Microsporium canis isolates by DNA Fingerprinting. Mycoses. 57 (8):507-512

[25] Ginter-Hanselmayer, G; Smolle, J. and Gupta, A. (2004).Itraconazole in the treatment of tinea capitis caused by Microsporium canis: experience in a large cohort.Pediatric Dermatology.21 (4): 499-502.

[26] Ben-Ami, R., Lewis, R. E. and Kontoyiannis, D. P. (2010).Enemy of the (immuno-suppressed) state: an update on the pathogenesis of Aspergillus fumigatus infection. British Journal of Haematology.150 (4):406-417.

[27] Segal, B. H. (2009). Aspergillus. New England Journal of Medicine.360 (18): 1870-1884.

[28] Pottier, I.; Gente, S; Vernoux, J.P. and Gueguen, M. (2008).Safety assessment of dairy microorganisms: Geotrichum candidum. International Journal of Food Microbiology.126 (3):327-332.

[29] Jain, N. and Sharma, M. (2011).Distribution of dermatophytes and other related fungi in Jaipur City with particular reference to soil $\mathrm{P}^{\mathrm{H}}$. Mycoses.54 (1): 52-58.
Rezusta, A; Betran, A; Querol, I; Palacian, M. P. and Revillo, M. J. (2011). Tinea capitis caused by Trichophyton soudanese and Microsporium audouinii in an adult: a case report. Mycoses.54 (1):89-90.

[30] Gugnani, H. C. (1992). A review of Zygomycosis due to Basidiobolus ranarum.European Journal of Epidemiology. 15 (10): 923-929.

[31] Groff, J. M; Mughannam, A; McDowell, T. S; Wong, A; Dysktra, M. J; Frye, F. L. and Hedrick, R. P. (1991). An epizootic of cutaneous zygomycosis in cultured dwarf African clawed frogs due to Basidiobolus ranarum. Medical Mycology.29 (4): 215-223.

[32] Sangwan, J; Lathwal, S; Juyal, D. and Sharma, N. (2013). Fonsecaea pedrosoi: a rare etiology in fungal keratitis. Journal of Clinical and Diagnostic Research.7 (10):2272-2273

[33] Deb Roy, A; Das, D. and Deka, M. (2013).Chromoblastomycosis-a clinical mimic of squamous carcinoma. Mycopathologia. 6 (9): 458-460.

[34] Nakagawa T., Nakashima, K; Takaiwa, T. and Negayama, K. (2000). Trichosporon cutaneum (Trichosporonasahii) infection mimicking hand eczema in a patient with leukemia. Journal of American Academy of Dermatology.42:929-930 